\title{
Is Modified Jones Model Effective in Detecting Earnings Management? Evidence from A Developing Economy
}

\author{
Md. Aminul Islam (Corresponding author) \\ Assistant Professor, School of Business Innovation and Technopreneurship \\ University Malaysia Perlis, Malaysia \\ E-mail: amin_shanto@yahoo.com and amin@unimap.edu.my \\ Ruhani Ali \\ Professor, Graduate School of Business \\ Universiti Sains Malaysia \\ Zamri Ahmad \\ Associate Professor and Deputy Dean, School of Management \\ Universiti Sains Malaysia
}

Received: August 18, 2010

Accepted: October 9, 2010

doi:10.5539/ijef.v3n2p116

\begin{abstract}
This study analyzes the effectiveness of Modified Jones Model in detecting earnings management among the initial public offerings that are listed between 1985 - 2005 in the Dhaka Stock Exchange (DSE). Prior research documented that the Modified Jones model is effective in detecting earning management in mostly developed economies. However recently an empirical research of Korean stock exchange revealed that the Modified Jones model was not effective in detecting earnings management in the context of Korea. Our findings are similar to the Korean experience. Results of our study confirmed that Modified Jones model is not effective in detecting earnings management in the context of Bangladesh. We employed the modified Jones model to detect earning management in context of Bangladesh capital market and found out that it was not found very effective as the explanatory power of the model was only about 9 percent. This study then attempted to extend the modified Jones model and found it to be very successful. The inclusion of few factors such as revenue, depreciation expenses, retirement benefit expenses, asset disposal gains/losses with the modified model was very effective in detecting earning management in the context of Bangladesh. The explanatory power of the model was increased to about 84 percent. Therefore it is concluded that the modified Jones model is not effective in gauging the extent of earnings management practiced by the IPO firms in the Bangladesh capital market.
\end{abstract}

Keywords: Earning management, Modified Jones Model, Dhaka Stock Exchange

\section{Introduction}

Studies of short run and long run behavior of returns on IPOs reveal that IPOs are underpriced in the short run, whereas in the long run the evidence is that of underperformance, i.e., negative returns accrue to the investors holding these IPOs (Balwinder Singh and RK Mittal, 2003). IPO firms can enhance their earnings by adopting discretionary accounting accrual adjustments that raise reported earnings. Over time, investors may recognize that the firms' earnings are not maintaining momentum, and hence, investors may lose their optimism, resulting in poor long run performance. Teoh et al., (1998) and Abdullah and Susanne (2004) revealed that the offering firms report significant improvements in their operating performance in the pre-offer period, which are not due to their cash flow performance. They have also recorded that an aggressive earnings management pre-offer leads to worse operating and return performance post-offer. Most of the prior studies on earnings management have focused on why firms manage earnings. Several reasons have been identified that include; income smoothing (Yoon and Miller, 2002b), ownership control (DeAngelo, 1988), equity offerings (Rangan, 1998; Teoh et al., 1998; Yoon and Miller, 2002a) and political costs (Jones, 1991).

Researchers found it arduous and challenging to detect or measure earnings management. It is not possible to observe earnings management directly. Therefore, researchers have investigated two venues for earnings management, the choice of accounting methods and the management of accruals. Past research in their attempt to study accruals use two models: Healy (1985) and DeAngelo (1986) use total accruals as a proxy for earnings management while Jones (1991), Dechow, Sloan and Sweeney (1995), Rangan (1998), Teoh et al. (1998a) and Teoh et al. (1998b) use discretionary 
accruals as a measure of earnings management. The possible explanation to exclude non-discretionary accruals is that since non-discretionary accruals are used to reflect business condition; subject to firms condition and sales growth and thus it cannot be controlled by managers, it is excluded from the studies. The most popular discretionary model is the standard Jones (1991) model. This model is able to decompose accruals into discretionary and non-discretionary accruals. When changes in sales are adjusted for the change in receivables, standard Jones model becomes a modified Jones model, which is proposed by Dechow et al. (1995). The modified model is designed to reduce the measurement error of discretionary accruals when discretion is applied over sale. The study by Dechow et al.(1995) finds that a modified Jones model provides the most powerful test of earnings management compared to Healy DeAngelo and standard Jones and industry model. However a recent study by Yoon et al., (2006) document that the Modified Jones model is not effective in measuring discretionary accruals for Korean firms. Therefore this study attempted to find out whether modified Jones Model is effective in detecting earnings management in a developing economy, Bangladesh.

This study is useful for a number of reasons: firstly, to the best of knowledge, this is the first known study of this kind that focuses on earnings management of IPO firms for the Bangladesh stock market. Secondly findings of this study will (i) help policy makers to formulate appropriate policies to tackle misreporting of earnings and (ii) help the researcher to confirm whether modified Jones model is effective to detect earnings management in the Bangladesh capital market. Thirdly, the results of this study will be of great interest to academics, policy makers and investors both at home and abroad. Finally, it may also be useful for international organizations (such as the World Bank) and foreign governments who are interested in the development of capital markets in the emerging countries.

\section{Bangladesh capital market - an overview}

Bangladesh capital market is quite small compared to both other regional markets and to the size of its economy. Though generally a capital market has two prongs, the stock market and the debt market, Bangladesh market has only stock market in active operation, as a debt market is still in its incipient stage. However, the stock market is also considerably small due to lack of incentives and local business culture.

Among over 40,000 small and medium companies only 310 have become listed till April 30, 2007, of which 33 have been de-listed in the past 15 years. Though the governments tried their best to attract the growing private companies to turn their enterprises into public limited and get listed to reap benefits and avail incentives offered time to time, on average only 10 companies have joined the market each year.

Though industrialization has picked pace in Bangladesh almost three decades back, capital market has failed to attract the entrepreneurs as the key source of capital, which has usually been occupied by the banking system since beginning. That is why Bangladesh capital market has the lowest market capital as percentage of GDP in the region as well as other similar sized economies, as the following table shows, while its neighboring country India, sharing almost the same industrial history, has the highest (Table 1).

Bangladesh has two Stock Exchanges, Dhaka Stock Exchange (DSE), established in 1954 where trading is conducted by Computerized Automated Trading System and Chittagong Stock Exchange (CSE), established in 1995 which is also conducted by Computerized Automated Trading System. All exchanges are self-regulated, private sector entities which must have their operating rules approved by the Securities and Exchange Commission (SEC).

To be listed on the DSE or CSE, a firm must get approvals from the Securities and Exchange Commission (SEC) and the DSE/CSE itself. Approvals from the DSE/CSE are easier to get compared to SEC. SEC might approve, amend or reject a firm's request for listing. To get an approval from SEC, a firm must meet certain criteria and must submit an application to SC. In the application, a firm must state, among other things, the price at which the shares will be offered or the offer price, the number of shares to be offered, the purpose of the initial public offering (IPO), the use of the proceeds to be raised from the IPO, the riskiness of investing in the firm's shares, the financial performance for the past three years, the value of landed properties if a valuation exercise is undertaken, and the ownership structure of the firm. After getting an approval, a firm publishes a prospectus.

As of 31 December 2006 the total issued capital of all listed securities of Dhaka Stock Exchange was TK 71,745 million (US\$1037 million) where as in Chittagong Stock Exchange the total issued capital was TK 68,554.72 million (US\$979.35 million). The table 2 presents a summary of Bangladesh capital market. Total market capitalization of all securities listed with the Dhaka Stock Exchange was TK 3,23,368 million (US\$4673 million) as on 31 December 2006 compared to TK 2,67,480 million (US\$3821.14 million) in the Chittagong Stock Exchange (Table 2)

\section{Literature review}

An abundance of literature has surfaced in the area of earnings management. Potential earnings management has become a concern throughout the world. Earnings management occurs when managers use judgment in financial reporting and in structuring transactions to alter financial reports. The objective is to either mislead some stakeholders about the underlying economic performance of the company or to influence contractual outcomes that depend on reported accounting numbers (Healy and Wahlen, 1999). Many studies have examined management's choice of 
accounting methods, while other research has studied accrual management. As stipulated under Generally Accepted Accounting Principles (GAAP), managers may choose among various accounting policies that affect reported income differently. Most past researches were carried out in the United States market and some of them are described in the following sections.

According to Cormier and Magnan (1996), research supports the economic and financial theory assumption that managers make accounting choices to maximize their personal interests and well-being. An accounting choice that is economically beneficial for managers will be preferred to manage earnings because they generally do not require disclosure and often will not be questioned by an auditor.

Schipper (1989) defines earnings management as 'a purposeful intervention in the external financial reporting process with the intention of obtaining some private gains'. As DuCharme et al. (2000) point out, pure earnings management techniques available to managers tend to fall within three broad categories: choice of accounting methods, revision of estimates and acceleration of deferral of revenues and expenses. At any point of time, some of the firm's future revenues and costs are genuinely uncertain and while no set of hard and fast rules can help to solve it and inevitably, there are instances where firm exercise judgment and thus opens room for firms to manage earnings. It is not surprising that managers, in their judgment, believe that they are acting in the firm's best interest. In particular, without violating accounting rules, firms can accelerate the recognition of revenues and defer the recognition of certain expenses under business environment.

Economic and financial theory assumes that managers are, by nature, rational and opportunistic in the pursuit of their personal interests (Cormier and Magnan (1996). These interests are determined by the terms set out in contracts between managers and the company, as well as in contracts between the company and specific external parties such as suppliers, lenders, governments and regulators. Many of these contracts are based on earnings or other financial information issued by the company. For example, senior executives often receive bonuses based on accounting income; and debt often has covenants that state minimum working capital amounts, establish maximum debt-to-equity ratios or restrict dividends based on the amount of retained earnings. An accounting choice that is economically beneficial for managers will be preferred over a choice with negative repercussions: it is assumed that the manager will adopt a "strategic" approach in his or her accounting choices. The study of the effect of contract terms on accounting choices is known as contracting theory or positive accounting theory.

Initial studies based on this theory focused on the reasons that motivate managers for choosing accounting policies. Such policies include capitalizing versus expensing interest payments, using accelerated depreciation rather than the straight-line method, and deciding on whether to capitalize research and development costs. In general, research supports the assumption that managers make accounting choices to maximize their personal interests and well-being. However, examining accounting policy choices tells only part of the story. Researchers have come to realize that (1) firms do not and cannot constantly change accounting policies; (2) managers do not choose an accounting policy without considering the firm's accounting procedures "portfolio"; and (3) earnings according to generally accepted accounting principles (GAAP) may be influenced by factors other than the choice of accounting policy. These limits have led researchers to examine whether managers use accruals (the difference between net earnings and cash flow) to accomplish their interests.

This approach seems logical: accruals represent the overall measurement of a firm's accounting disclosure policy, and they are more likely to reflect a strategic decision made by the firm's managers than simply the study of a particular accounting choice. Accruals are also an attractive way for managers to manage earnings because they generally do not require disclosure and often will not be questioned by an auditor. It's important to note that earnings management is not the same as earnings manipulation. Earnings management, however, complies with GAAP whereas earnings manipulation does not.

Neill, Pourciau and Schaefer (1995) report that, proceeds from the initial offering of IPO using income-increasing (liberal), for example borrowing aggressively from future earnings, are relatively higher than those using income-decreasing (conservative) methods when analyzing accounting method choice. Thus, there is incentive for issuing firms to manage earnings to raise enough capital when the investors foresee the share price to increase. In addition, managers personally can earn abnormal profits when they sell their shares. Managers attempt to manipulate earnings in order to influence short-term stock price performance and also for job security.

However, aggressive management of earnings through income-increasing accounting adjustments leads investors to be overly optimistic about the issuer's prospect and thus overvalues the new issues (Abdullah et al. 2004). When these high pre-issue earnings are not sustained over time, disappointed investors subsequently will devalue the firm.

Inevitably, according to Rangan (1998), managers will continue to manage earnings in the subsequent two quarters after the offering announcement for two reasons:

1. an earnings reversal immediately after the offering and the associated price drop could invite lawsuits against the firm and its manager 
2. firms enter into lock-up agreements with their underwriters that prevent insiders at issuing firms from selling their holdings until 90 to 180 days after the offering date.

\subsection{Earnings Management in Seasoned equity and Initial Public Offerings}

Many past literatures such as Loughran and Ritter (1997), Rangan (1998) and Teoh et al (1998a) provide evidence that managers manage earnings during seasoned equity offerings in the US market. These studies report that earnings management during seasoned equity offerings causes poor long run stock performance. During seasoned equity, reported earnings are high due to high discretionary accruals component. There is a negative relation between discretionary accruals and post-offering abnormal stock returns. The high discretionary accruals tend to predict worse stock price performance. Stock price under-perform, as investors are disappointed with subsequent earnings decline.

Alireza D. and Daniel Z. (2003) indicated that the mean of abnormal accruals was statistically significant and the sign of abnormal accruals was positive. Their findings also indicated that the changes in accruals had an increasing effect on reported earnings numbers and earnings were managed upward.

Teoh et al. (1998a) in their hypothesis predicts worse performance for issuers with usually large income-increasing accounting adjustments prior to the offering. Interesting, their research reveal that issuers in the most 'aggressive' quartile underperform the matched non-issuers by $7.5 \%$ in the three years after the issue year and also they underperform conservative issuers. In contrast, issuers conservatively outperform their match.

Pre-offering shareholders of issuing firms benefit from misevaluations of share prices that are caused by earnings management. Rangan (1998) also provides evidence to reject the notion that issuing firms are simply timing their offerings after quarters of high earnings and are not manipulating earnings and that at least a portion of the discretionary accruals represents deliberate earnings management. Rangan's study differs from Loughran and Ritter (1997) and Teoh et al. (1998a) because the only stock returns following the offering year and not the long-term performance. According to Shivakumar (2000), managers of offering firms manipulate earnings not to influence investor valuations but as a rational response to the expected negative market reaction at the announcement.

Tan (2001) in his study finds that there is an under performance trend in stock price in the post announcement period with the highest stock returns occur prior to or in the year of the rights issues announcement. As expected with discretionary accruals, the general pattern of pre-issue earnings management, for instance higher discretionary accrual quartile, shows better pre-issue earnings performance than the lower discretionary current accruals and cannot predict post-issue stock return under performance.

In more recent years, several studies have examined earnings reporting around IPOs of common stock. Among others, Teoh et al. (1998b), DuCharme et al. (2000), Abdullah et al., (2004), Yoon and Miller (2002b), Yoon et al., (2006) all report empirical evidence that suggests earnings are managed in anticipation of going public. It is unclear if the measures of earnings management employed in this research can truly reflect the deceptive nature of manipulation of revenues and expenses intended to enhance reported earnings (and, thereby, IPO proceeds), or reflective of normal operating, investing and financing decisions of IPO firms. It is difficult to distinguish legitimate earnings reporting from subtly misleading practices, and there is no generally accepted method of doing so. If it is costly for management to mislead investors, then discretionary accounting choices might be focused on increasing the information content of reported earnings.

Ritter (1991) provides empirical evidence that IPO firms' stock returns are significantly less than those of a matched sample of non-IPO firms over the three-year period after offering. His study implies that entrepreneurs mislead investors by manipulating earnings and investors react negatively. This finding is further supported by Jain and Kini (1994) who examine accounting measures of operating performance of IPO firms. They find that firms exhibit a decline in operating performance after their IPOs as a result of not being able to further borrow from future high expectations of future earnings growth that are not subsequently fulfilled.

Teoh et al. (1998b) also investigate earnings management during the year of IPO and subsequent stock returns. They find a significant negative association between abnormal accruals measured during the year of offer and stock returns over a three-year post IPO period. Teoh et al. (1998b) report issuers with unusual high accruals in the IPO year experience poor stock return performance in the three years thereafter. IPO issuers in the most 'aggressive' quartile of earnings' managers have a three-year after market stock return of approximately $20 \%$ less than IPO issuers in the most 'conservative' quartile.

According to DuCharme et al. (2000), pre-IPO abnormal accruals are positively related to initial firm value. Their results also confirm the earlier studies: abnormal accruals during the offer year are significantly negatively related to subsequent form stock returns. In addition, they also find that abnormal accruals in the preceding year are also significantly negatively related to subsequent performance. 


\subsection{Discretionary Accruals Model}

How can we measure earnings management? It is not possible to observe earnings management directly. Therefore, researchers have investigated two venues for earnings management, the choice of accounting methods and the management of accruals. Previous work on accruals focused mainly for the fiscal year of IPO.

According to DuCharme et al. (2000) accruals models are preferred because this approach captures the subtle income management techniques allegedly used to avoid detection by outsiders. Accruals not only reflect the choice of accounting methods but also the effect of recognition timing for revenues and expenses, asset write-downs and changes in accounting estimates.

Past research in their attempt to study accruals use two models: Healy (1985) and DeAngelo (1986) use total accruals as a proxy for earnings management while Jones (1991), Dechow, Sloan and Sweeney (1995), Rangan (1998), Teoh et al. (1998a) and Teoh et al. (1998b) use discretionary accruals as a measure of earnings management. The possible explanation to exclude non-discretionary accruals is that since non-discretionary accruals are used to reflect business condition; subject to firms condition and sales growth and thus it cannot be controlled by managers, it is excluded from the studies.

The distinction between discretionary and non discretionary components of accruals is important. In earnings management, it is accruals that change as a result of management's accounting decisions that are of interest, which is discretionary accruals. Discretionary accruals represent managerial interventions into financial reporting process.

Researchers face a difficult problem distinguishing between discretionary and non-discretionary components of accruals. The distinction is important. While changes in a company's underlying performance will cause non-discretionary accruals to change, it is accruals that change as a result of management's accounting decisions that are of interest. For example, during a period of economic growth, one would expect accruals such as accounts receivable and accounts payable to change as sales increase without any earnings management occurring. In contrast, discretionary accruals represent managerial interventions into the financial reporting process. For example, if the allowance for doubtful accounts were changed because of management's self-interest, the change in accruals would be discretionary.

Accruals include all adjustments that allow a business to change from a cash basis to an accrual basis - whether this means allocations, provisions or changes in accounting methods. Changes in working capital also form part of accruals. The following equation demonstrates the calculation:

\section{Total accruals $=$ earnings - cash flow (from operations)}

The trick for researchers is to identify the discretionary component of accruals. It is difficult to do this because non-discretionary and discretionary components of accruals cannot be observed directly, so it is necessary to develop methods for estimating the discretionary accruals. What researchers want to know can be shown as:

\section{Discretionary accruals + Non-discretionary accruals $=$ Earnings - Cash Flow (from operations)}

Researchers have developed several techniques for estimating discretionary accruals. One approach uses total accruals as an estimate of discretionary accruals and looks for earnings management by comparing the amount of accruals in different firms. A second method examines differences in accruals between periods. For example, a researcher might assume that non-discretionary accruals do not change between periods and attribute differences in total accruals to management discretion. Or, the researcher might adjust the estimate of non-discretionary accruals to reflect economic changes such as growth. A third approach uses regression techniques to separate the discretionary and non-discretionary components of accruals.

The most popular discretionary model is the standard Jones (1991) model. This model is able to decompose accruals into discretionary and non-discretionary accruals. When changes in sales are adjusted for the change in receivables, standard Jones model becomes a modified Jones model, which is proposed by Dechow et al. (1995). The modified model is designed to reduce the measurement error of discretionary accruals when discretion is applied over sale. The study by Dechow et al.(1995) finds that a modified Jones model provides the most powerful test of earnings management compared to Healy DeAngelo and standard Jones and industry model. However a recent study by Yoon et al., (2006) document that the Modified Jones model is not effective in measuring discretionary accruals for Korean firms.

Guay, Kothari and Watts (1996) conclude that both the Jones and modified Jones models provide reliable estimates of discretionary accruals as distinct to the study of Dechow et al. (1995). Peasnell, Pope and Young (2000) find that Jones and modified Jones models are able to generate powerful tests for earnings management and are more powerful for the revenue and bad debt manipulations than non bad debt manipulations. In tests comparing the power of the modified-Jones model with that of the standard Jones model, Dechow et al. (1995) find that the former procedure is indeed significantly better at detecting sales-based earnings management. 
Previous research examines the specification and power of various discretionary-accrual models, but not that of performance-matched accrual models (see Dechow, Sloan, and Sweeney,1995). Dechow et al. (1995, p. 193) conclude, "all models reject the null hypothesis of no earnings management at rates exceeding the specified test levels when applied to samples of firms with extreme financial performance." One interpretation of the results is that firms with extreme performance are more likely to engage in earnings management and that discretionary accrual models correctly detect it as such (see Guay, Kothari, and Watts, 1996). Alternatively, the discretionary accrual models might be misspecified when applied to samples of firms with extreme performances, in part because performance and estimated discretionary accruals exhibit a mechanical relation. To the extent that the concern is model misspecification, and because earnings management research typically examines non-random samples (e.g., samples that firms self-select into by, for example, changing auditors), earnings management studies must employ some means of mitigating the misspecification to reduce the likelihood of incorrect inferences. In this vein, use of a control sample to address specification issues is common in the literature.

\section{Data and methodology}

This study will examine new companies, which were listed on the DSE for the period 1995-2005. The lists of new listings were obtained from the various issues of the Securities and Exchange Commission (SEC) Annual Report. A total of 142 companies listed at DSE during the study period were selected for this study. All the data used in this study are secondary data gathered from prospectuses, DSE Daily Diaries, DSE website, and annual Report of listed Companies.

The population of this study includes all listed companies in DSE. This study includes IPO issuers in all sectors such as Financial sector that include Bank, Insurance and Investment; Manufacturing sector that include Cement, Engineering, Ceramics, Food and Allied products, Jute, Paper and Printing, Pharmaceuticals and Chemicals, Tannery Industry and Textiles. Finally Service \& miscellaneous that include Fuel and Power, IT, Services and Real Estates, and Miscellaneous

Discretionary accruals are used as a proxy to determine the extent of earnings management. Discretionary accruals are obtained by subtracting non-discretionary accruals from total accruals. Non-discretionary accruals are estimated by using a regression model that regresses total accruals on several explanatory variables. However, a critical drawback to the total accrual approach is that we can not distinguish discretionary components from non-discretionary components. Therefore a model needs to be developed to separate discretionary accruals from total accruals. Prior research documents that the modified Jones model (Dechow et al., 1995) is effective. However, recently Yoon and Miller (2002b), and Yoon et al., (2006) document that the modified Jones model does not fit for Asian firms (Korean firms). Therefore the new model proposed by Yoon et al., (2006) were employed in this research. The model is described in equation 1 :

$$
\mathrm{TA}_{\mathrm{i}} / \mathrm{REV}_{\mathrm{i}}=\beta_{0}+\beta_{1}\left(\Delta \mathrm{REV}_{\mathrm{i}}-\Delta \mathrm{REC}_{\mathrm{i}}\right) / \mathrm{REV}_{\mathrm{i}}+\beta_{2}\left(\Delta \mathrm{EXP}_{\mathrm{i}}-\Delta \mathrm{PAY}_{\mathrm{i}}\right) / \mathrm{REV}_{\mathrm{i}}+\beta_{3}\left(\mathrm{DEP}_{\mathrm{i}}+\mathrm{RET}_{\mathrm{i}}\right) / \mathrm{REV}_{\mathrm{i}}+\varepsilon_{\mathrm{i}}
$$

Where

TA $($ Total accruals $)=$ accounting earnings $-\mathrm{CFO}$

$$
\begin{aligned}
& \mathrm{REV}=\text { net sales revenue } \\
& \mathrm{REC}=\text { receivables }
\end{aligned}
$$

$\mathrm{EXP}=$ sum of cost of goods sold and selling and general administrative expenses excluding non-cash expenses.

$\mathrm{PAY}=$ payables

$\mathrm{DEP}=$ depreciation expenses

RET $=$ retirement benefits expenses

$\Delta \quad=$ change operator.

The model posits that total accruals will normally depend on changes in cash sales revenue, changes in cash expenses and some non-cash expenses including depreciation expenses and retirement benefits expenses. In order to get the discretionary accruals, non-discretionary accruals will be subtracted from the total accruals for each observation in equation (ii) as follows:

$$
\mathrm{DA}_{\mathrm{i}}=\mathrm{TA}_{\mathrm{i}} / \mathrm{REV}_{\mathrm{i}}-\left[\mathrm{b}_{0}+\mathrm{b}_{1}\left(\Delta \mathrm{REV}_{\mathrm{i}}-\Delta \mathrm{REC}_{\mathrm{i}}\right) / \mathrm{REV}_{\mathrm{i}}+\mathrm{b}_{2}\left(\Delta \mathrm{EXP}_{\mathrm{i}}-\Delta \mathrm{PAY}_{\mathrm{i}}\right) / \mathrm{REV}_{\mathrm{i}}+\mathrm{b}_{3}\left(\mathrm{DEP}_{\mathrm{i}}+\mathrm{RET}_{\mathrm{i}}\right) / \mathrm{REV}_{\mathrm{i}}\right]
$$

\section{Results}

16 multiple regressions were employed to compare the explanatory power and models fitness between Modified Jones model and the extended modified Jones model. From the results it can be observed that modified Jones model's goodness of fit is poor compared to the extended model. More specially, as far as $\mathrm{R}^{2}$ are concerned, it is only 8.9 
percent as compared to 83.8 percent in the extended model. Among the three explanatory variables, only the change in cash revenues (REV - REC) / BTA show consistent and significant explanatory powers. The inverse of firm size, 1/BTA and GPPE/BTA (gross property, plant and equipment), do not have any meaningful power in explaining the variation of total accruals in the sense that they do not show consistent directional relationship with discretionary accruals in a statistically significant manner. If $\mathrm{R}^{2}$ of the seven industries are compared, $\mathrm{R}^{2}$ in all industries regression are higher in the extended model except the pharmaceuticals and chemical industry. The results are presented in the table 3. (Table 3)

Then what are the explanatory variable, which is presumed to proxy for firm size, is in fact a constant, from the equation of "total accruals $=$ current accruals + non-current accruals", we can set up a regression equation "total accrual $=\beta 0+\beta 1$ current accruals $+\beta 2$ non-current accruals $+\varepsilon$ " Using proxy variables for the current and non-current accruals, we can transform the regression into "TA $=\beta 0+\beta 1$ (REV - REC) $+\beta 2$ GPPE $+\varepsilon$ ". Then by standardizing the regression equation by beginning total assets (BTA) to eliminate heteroscedasticity, we get "TA/BTA $=\beta 0(1 / \mathrm{BTA})+$ $\beta 1(\mathrm{REV}-\mathrm{REC}) / \mathrm{BTA}+\beta 2(\mathrm{GPPE} / \mathrm{BTA})+\varepsilon "$, which is the modified Jones model.

We can infer that the inverse firm size is nothing but a constant, derived in the process of standardization. Therefore, the inverse firm size is not expected to have any proportional relationship with total accruals by instruction. Furthermore, because of the inclusion of the inverse firm size in place of a constant, the regression model does not allow a new constant term. This further reduces the explanatory power of the modified Jones model.

Management may utilize not only sales (like front-loading of credit sales) but also expenses in managing reported earnings. Hence, unless we properly take into account both cash sales and cash expense, we may not properly capture the dual aspects of current accruals. One of the major weaknesses of the modified Jones model is that the change in cash sales does not have a predicted relationship with total accruals. Total accruals will have a certain relationship with current accruals.

However, it is difficult to predict the relationship the changes in cask sales will have with total accruals. Therefore, the predicted relationship can be either positive or negative. Sometimes, sales and receivables will be utilized to manage earnings, whereas at other times expenses and payables can be utilized for the same purpose. If we include only the first variable in the extended model, we may in fact capture the impact of cash expenses are corrected. In addition, GPPE is a proxy variable for depreciation expense, which in turn is a proxy for non-current accruals. We can pinpoint two problems with respect to this variable. One is that an omnipresent non-discretionary and non-cash expense is retirement benefit expense. Unlike the funded pension liabilities in the case of USA and many other countries, the retirement benefit liabilities for many of the Bangladeshi firms are under-funded liabilities and hence the majority of retirement benefit expense is a non-cash expense. Therefore, we should take this into account when we select a proxy variable for the non-current accruals in Bangladesh. The other is that there is a mismatch between numerator and denominator of the third variable in the modified Jones model. GPPE is a stock variable while non-current accrual is a change variable as mentioned above. This is why we used (DEP+RET)/REV to proxy for non-current accruals, sum of depreciation expense and retirement benefit expense deflated by the same period revenues. These have contributed high explanatory power of the extended model as compared to Modified Jones Model.

Previous researchers in their attempt to detect earning management using accruals used two models: Healy (1985) and DeAngelo (1986) use total accruals as a proxy for earnings management while Jones (1991), Dechow, Sloan and Sweeney (1995), Rangan (1997), Teoh et al. (1998a) and Teoh et al. (1998b) use discretionary accruals as a measure of earnings management. The possible explanation to exclude non-discretionary accruals is that since non-discretionary accruals are used to reflect business condition; subject to firms condition and sales growth and thus it cannot be controlled by managers, therefore it was excluded from these studies. This research adopted the later approach. Discretionary accruals were used as proxy to earning management.

Prior research documents that the modified Jones model (Dechow et al., 1995) is effective. However, recently Yoon and Miller (2002b), and Yoon et al., (2006) documented that the modified Jones model does not fit for Korean firms. Therefore this research adopted an extended modified model by incorporating few additional variables i.e., depreciation expenses, bad debt expenses, retirement benefit expenses, and current period expenses. However bad debt expenses were later excluded from the model due to unavailability of data. None of the sample $(n=1000)$ firms declared bad debt expenses in their annual report. These inclusions have substantial impact the explanatory of the extended model. The $\mathrm{R}^{2}$ increased from 9 percent to 83 percent. This indicates that the extended model used in this study is more effective in detecting earning management than that of modified Jones model. This finding is consistent with Yoon et al., (2006) findings. They found out that modified Jones model was not effective in detecting earning management for Korean firms. Findings of this study confirmed that modified Jones model is less effective in detecting earning management for Bangladeshi firms as compared to the extended model used in this study. Therefore it can be concluded that the extended model used model for this study is more powerful and effective in detecting earning management. 


\section{Conclusion}

Over the years modified Jones model was considered the most powerful tool in detecting earning management. This has been documented in many developed countries i.e., USA, UK and few other countries i.e., Malaysia, Taiwan, and India etc. However the modified Jones model was found to be less effective in gauging the level of earning management in the Bangladesh capital market. An extended model has been proposed which is found to be more effective in detecting earning management. In the original modified Jones model the beginning total assets, current period revenues, and balance of trade accounts receivable at year-end, and gross property, plant and equipment at year-end are the significant factors to detect earning management. However we extended the model by incorporating current period expenses, trade accounts payable at year-end, depreciation expense, and retirement benefits expense. The inclusion of these few variables significantly increased the explanatory power in detecting earning management.

\section{References}

Abdullah Iqbal, Susanne Espenlaub \& Norman Strong. (2004). Earning Management Around UK Open Offers, Working Paper Series, Kent Business School, University of Kent.

Alireza, D. \& Daniel, Z. (2003). Earnings Management and the Stock Market Environment, Discussion paper, University of New Haven, USA.

Balwinder Singh \& RK Mittal. (2003). Underpricing of IPOs: Indian Experience. The ICFAI Journal of Applied Finance, 9(2), p.29.

Cormier, D. \& Magnan, M. (1996). Decision, decisions, CA Magazine, 129(7), 38.

DeAngelo, L. (1986). Accounting numbers as Market Valuation Substitutes: A Study of Management Buyouts of Public Stockholders, The Accounting Review, July, 400-420.

Dechow, P.M., R.G. Sloan \& A.P. Sweeney. (1995). Detecting Earnings Management, The Accounting Review, 70, 193-225.

DuCharme, L.L., P.H. Malatesta, \& S.E. Sefcik. (2000). Earnings Management: IPO Valuation and Subsequent Performance, Working paper, University of Washington.

Guay, W., S.P. Kothari, \& R.L. Watts. (1996). A Market-Based Evaluation of Discretionary Accruals Model, Journal of Accounting Research, 34, 83-105. doi:10.2307/2491427, http://dx.doi.org/10.2307/2491427

Healy, P.M. (1985). The Effect of Bonus Schemes on Accounting Decisions, Journal Accounting and Economics, April, 85-107. doi:10.1016/0165-4101(85)90029-1, http://dx.doi.org/10.1016/0165-4101(85)90029-1

Healy, P. \& Wahlen, J.M. (1999). A Review of the Earnings Management Literature and its Implications for Standard Setting, Accounting Horizon, 13(4), 365-384. doi:10.2308/acch.1999.13.4.365, http://dx.doi.org/10.2308/acch.1999.13.4.365

Jones, J. (1991). Earnings Management during Import Relief Investigations, Journal of Accounting Research, 29, 193-228. doi:10.2307/2491047, http://www.jstor.org/pss/2491047

.McNichols, M. \& P. Wilson. (1998). Evidence of Earnings Management from the provision for bad-debts, Journal of Accounting Research 26, pp. 1-31. doi:10.2307/2491176, http://dx.doi.org/10.2307/2491176

Neill, J.D., Pourciau, S.G. \& Schaefer, T.F. (1995). Accounting Method Choice and IPO Valuation, Accounting Horizons, 9(3), 68.

Peasnell, K. Pope, P. \& Young, S. (2000). Detecting Earnings Management using Cross-Sectional Abnormal Accruals Models, Accounting and Business Research, 30(4), 313-326.

Rangan, S. (1997). Earnings Management and the Performance of Seasoned Equity Offerings, Journal of Financial Economics, 50, 101-122. doi:10.1016/S0304-405X(98)00033-6, http://dx.doi.org/10.1016/S0304-405X(98)00033-6

Rendleman Jr., R.J., Jones, C.P. \& Latane, H.A. (1982). Empirical anomalies based on unexpected earnings and the importance of risk adjustment. Journal of Financial Economics 10 3, pp. 269-287. doi:10.1016/0304-405X(82)90003-4, http://dx.doi.org/10.1016/0304-405X(82)90003-4

Schipper, K. (1989). Earnings Management, Accounting Horizons, 3 (4), 91-102.

Shivakumar, L. (2000). Do firms mislead investors before seasoned equity offerings? Journal of Accounting and Economics 29, 339-370. doi:10.1016/S0165-4101(00)00026-4, http://dx.doi.org/10.1016/S0165-4101(00)00026-4

Shivakumar, L. (1997). Market reaction to seasoned equity offering announcements and earnings management. Working Paper, London Business School, London, UK.

Sloan, R. (1996). Do Stock Prices Fully Impound Information in Accruals About Future Earnings?, Accounting Review, 71, 289-315. 
S.P. Kothari, Andrew J. Leone \& Charles E. Wasley. (2004). Performance Matched Discretionary Accrual Measures, Sloan School of Management, Massachusetts Institute of Technology.

Soon Suk Yoon, Gary Miller \& Pornsit Jiraporn. (2006). Earnings Management Vehicles for Korean Firms, Journal on International Financial Management and Accounting 17/2. New York.

Su, D. (2002). Stock price reactions to earnings announcements: Evidence from Chinese markets, Review of Financial Economics, 1 -21.

Tan, C.T. (2001). Performance of Rights Issues and Earnings Management. An Empirical Evidence from Malaysia, MBA thesis, School of Management, Universiti Sains Malaysia, Penang.

Teoh, S.H., I. Welch, \& T.J. Wong. (1998a). Earnings Management and the Under Performance of Seasoned Equity Offerings, The Journal of Financial Economics, 50, 63-99. doi:10.1016/S0304-405X(98)00032-4, http://dx.doi.org/10.1016/S0304-405X(98)00032-4

Teoh, S.H., I. Welch \&T.J. Wong. (1998b). Earnings Management and the Long Run Market Performance of Initial Public Offerings, The Journal of Financial LIII (6), 1935-1974. doi:10.1111/0022-1082.00079, http://dx.doi.org/10.1111/0022-1082.00079

Teoh, S.H., T.J. Wong \& G. Rao. (1999). Are Accruals during an Initial Public Offering Oportunistic? Review of Accounting Studies (Forthcoming).

Yoon, S. \& G. Miller. (2020a). Earnings Management of Seasoned Equity Offering Firms in Korea, International Journal of Accounting 37, pp. 57-68.

Yoon, S. \& G. Miller. (2002b). Cash from Operations and Earnings Management in Korea, International Journal of Accounting 37, pp. 395-412. doi:10.1016/S0020-7063(02)00193-0, http://dx.doi.org/10.1016/S0020-7063(02)00193-0

Yoon, S., G. Miller \& Jiraporn P. (2006). Cash from Operations and Earnings Management in Korea, Journal of International Financial Management and Accounting, pp. 85-109. doi:10.1111/j.1467-646X.2006.00122.x, http://dx.doi.org/10.1111/j.1467-646X.2006.00122.x

Website visited:

- $\quad$ www.secbd.org

- $\quad$ www.dsebd.org

- $\quad$ www.cse.com.bd

Table 1. Market capital as percentage of GDP (As of December 2006)

\begin{tabular}{|clrrr|}
\hline Sl & Country & GDP Size & $\begin{array}{c}\text { Market Capital of the } \\
\text { listed stocks }\end{array}$ & Market Capital as Percentage of GDP \\
01. & South Korea & $\$ 886.00 \mathrm{~b}$ & $\$ 824.00 \mathrm{~b}$ & $93.0 \%$ \\
02. & India & $\$ 750.00 \mathrm{~b}$ & $\$ 810.00$ & $108.0 \%$ \\
03. & Indonesia & $\$ 353.00 \mathrm{~b}$ & $\$ 134.00 \mathrm{~b}$ & $38.0 \%$ \\
04. & Iran & $\$ 182.00 \mathrm{~b}$ & $\$ 38.30 \mathrm{~b}$ & $21.0 \%$ \\
05. & Malaysia & $\$ 150.00 \mathrm{~b}$ & $\$ 160.00 \mathrm{~b}$ & $106.67 \%$ \\
06. & Pakistan & $\$ 127.00 \mathrm{~b}$ & $\$ 48.00 \mathrm{~b}$ & $41.0 \%$ \\
07. & Philippines & $\$ 117.00 \mathrm{~b}$ & $\$ 73.70 \mathrm{~b}$ & $63.0 \%$ \\
08. & Bangladesh & $\$ 62.02 \mathrm{~b}$ & $\$ 8.47 \mathrm{~b}$ & $15.0 \%$ \\
09. & Vietnam & $\$ 61.00 \mathrm{~b}$ & $\$ 14.00 \mathrm{~b}$ & $23.0 \%$ \\
\hline
\end{tabular}

Source: www.devdata.worldbank.org 
Table 2. Bangladesh capital market - At a glance

\begin{tabular}{|c|c|c|c|c|c|c|}
\hline \multicolumn{3}{|l|}{ Indicators } & $D S E$ & \multicolumn{2}{|l|}{ CSE } & Total \\
\hline \multicolumn{3}{|l|}{ No. of companies } & 255 & \multicolumn{2}{|l|}{199} & 454 \\
\hline \multicolumn{3}{|l|}{ No. of mutual funds } & 13 & \multicolumn{2}{|l|}{13} & 26 \\
\hline \multicolumn{3}{|l|}{ No. of debentures } & 8 & \multicolumn{2}{|l|}{1} & 9 \\
\hline \multicolumn{3}{|l|}{ No. of treasury bonds } & 34 & \multicolumn{2}{|l|}{-} & 34 \\
\hline \multicolumn{3}{|l|}{ Total No. of Listed securities } & & 213 & 525 & \\
\hline & & \multicolumn{5}{|c|}{ Figures in million } \\
\hline \multicolumn{3}{|c|}{ No. of shares of all listed companies } & 1546.05 & 1414.49 & \multicolumn{2}{|c|}{$2,960.54$} \\
\hline \multicolumn{3}{|c|}{ No. of certificates of all listed mutual funds } & 161.25 & \multicolumn{2}{|l|}{161.25} & 322.50 \\
\hline \multicolumn{3}{|c|}{ No. of debentures of all listed debentures } & 0.41 & \multicolumn{2}{|l|}{0.05} & 0.46 \\
\hline \multicolumn{3}{|l|}{ No. of all listed bonds } & .45 & - & 0.45 & \\
\hline Total No. of tradable Secu & ities & & & 1575.79 & 3,2 & \\
\hline & Figures in mi & ion & & & & \\
\hline & $D S E$ & & CSE & & TOTAL & \\
\hline & Taka & US\$ & Taka & $U S \$$ & Taka & US \$ \\
\hline $\begin{array}{l}\text { Issued capital of all } \\
\text { companies }\end{array}$ & 71,745 & 1037 & $68,554.72$ & 979.35 & $140,299.72$ & $2,016.35$ \\
\hline $\begin{array}{l}\text { Issued capital of all } \\
\text { mutual funds }\end{array}$ & 735 & 11 & 735 & 10.50 & 1,470 & 21.50 \\
\hline Issued debentures & 140 & 2 & 25.65 & .37 & 165.65 & 2.37 \\
\hline Issued bonds & 45,817 & 662 & - & - & 45,817 & 662 \\
\hline Total Issued capital & 1,18437 & 1711.52 & $69,315.37$ & 990.22 & $187,752.37$ & $2,701.74$ \\
\hline $\begin{array}{ll}\text { Total } & \text { Market } \\
\text { Capitalization } & \end{array}$ & $3,23,368$ & 4673 & $2,67,480$ & 3821.14 & $5,90,840$ & $8,494.14$ \\
\hline
\end{tabular}

(Source: www.secbd.org)

Table 3. Comparison between Modified Jones Model (Note 1) and extended modified Jones Model (Note 2)

\begin{tabular}{|l|l|l|l|l|l|l|l|l|l|l|l|l|}
\hline & \multicolumn{9}{|l|}{ Modified Jones Model } & \multicolumn{4}{l|}{ Extended Model } \\
\hline Industry & $\mathrm{n}$ & $\mathrm{X}_{1}$ & $\mathrm{X}_{2}$ & $\mathrm{X}_{3}$ & $\mathrm{R}^{2}$ & $\mathrm{Y}_{1}$ & $\mathrm{Y}_{2}$ & $\mathrm{Y}_{3}$ & $\mathrm{Y}_{4}$ & $\mathrm{R}^{2}$ \\
\hline Manufacturing & 16 & $4.3125 \mathrm{e}-$ & -.021 & .4310 & .619 & .237 & .5902 & -.159 & .0779 & .664 \\
\hline Financial & 26 & 1.865 & -1.40 & .0927 & .583 & .389 & -4.29 & -.864 & .0448 & .934 \\
\hline Food and Allied Products & 13 & $9 \mathrm{e}-009$ & -.079 & .2524 & .407 & .095 & -8.06 & -6.83 & 1.502 & 1.00 \\
\hline $\begin{array}{l}\text { Pharmaceutical and Chemicals; and } \\
\text { Paper and printing }\end{array}$ & 10 & 7.011 & 2.149 & 2.006 & .166 & 2.98 & -3.39 & 2.594 & 2.457 & .235 \\
\hline Tannery and Textiles & 25 & $4.388 \mathrm{e}-009$ & .059 & .4029 & .045 & 3.47 & -1.25 & -.998 & .2938 & .035 \\
\hline Services and Misc. & 10 & $8.61 \mathrm{e}-009$ & .0441 & .4276 & .319 & .103 & -.065 & .191 & .2155 & .947 \\
\hline Overall & 100 & $4.851 \mathrm{e}-009$ & -.358 & .3026 & .089 & .706 & -2.37 & -1.36 & .3274 & .838 \\
\hline
\end{tabular}

Note 1: Modified Jones Model: X1 = 1/BTA; X2 = $($ REV - REC $) / B T A ; X 3=$ GPPE/BTA. Where, BTA represents beginning total assets, REV current period revenues, REC balance of trade accounts receivable at year-end, and GPPE gross property, plant and equipment at year-end. Note 2: Extended modified Jones Model: $\mathrm{Y} 1=$ Constant; $\mathrm{Y} 2=(\Delta \mathrm{REV}-\Delta \mathrm{REC}) / \mathrm{REV} ; \mathrm{Y} 3=(\Delta \mathrm{EXP}-\Delta \mathrm{PAY}) / \mathrm{REV} ; \mathrm{Y} 4=(\mathrm{DEP}+\mathrm{RET}) / \mathrm{REV}$. Where, REV represents current period revenues, REC balance of trade accounts receivable at year-end, EXP current period expenses excluding depreciation expense and retirement benefits expense, PAY trade accounts payable at year-end, EDP depreciation expense, and RET retirement benefits expense. 